\title{
Recycling of moisture in Europe: contribution of evaporation to variability in very wet and dry years
}

\author{
B. Bisselink and A. J. Dolman \\ Department of Hydrology \& Geo-environmental Sciences, VU University, Amsterdam, The Netherlands
}

Received: 6 April 2009 - Published in Hydrol. Earth Syst. Sci. Discuss.: 21 April 2009

Revised: 2 September 2009 - Accepted: 7 September 2009 - Published: 24 September 2009

\begin{abstract}
Evaporation is a key parameter in the regional atmospheric water cycle. Precipitation recycling is defined as the contribution of water that evaporates from a region to precipitation within the same region. We apply a dynamic precipitation recycling model, which includes a dynamic moisture storage term, to calculate the warm season variability of the precipitation recycling over central Europe at a daily time scale for 2003 (dry) and 2006 (wet).

For the central part of Europe advection is the most important contributor to precipitation. In dry spells in both years 2003 and 2006, when moisture of advective origin diminishes, local evaporation becomes an important contributor to precipitation (negative feedback). In two dry periods (June 2003 and July 2006) where there is enough moisture storage in the soil to continue evaporation, precipitation recycling is enhanced. In case studies we follow the path of an air column for days with high precipitation recycling to discuss the role of moisture recycling in land-atmosphere interactions. For 2 days with enough moisture availability (28 May 2003 and 5 July 2006) moisture particles stay long in the study area due to weak winds. By following the paths we show that the air is transported over land for a very long distance before it precipitates. It thus takes a considerable amount of time to traverse the region and capture moisture of evaporative origin. However, we hypothesize that the precipitation falling on those days still originates (partly) from oceanic sources, but that the triggering of precipitation may itself be a result of enhanced instability induced by soils, which still have sufficient moisture storage. In dry periods with enough moisture available precipitation recycling acts as a mechanism to keep the precipitation at a stable level.
\end{abstract}

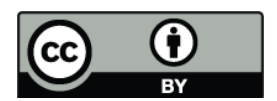

Correspondence to: B. Bisselink (berny.bisselink@falw.vu.nl)
In August 2003 evaporation is affecting the precipitation recycling due to the lack of water availability caused by the dryness of the preceding spring and summer season. According to a Granger Causality test the evaporation in 2003 exerts the strongest causal impact on the precipitation recycling ratio. For the case study of 10 August 2003, the atmosphere is too dry to generate precipitation with exception of the mountainous regions due to orographical lifting.

\section{Introduction}

Land-atmosphere interactions play an important role in our climate system. Recently there has been an increasing interest in how future climate and/or land-use change may effect evaporation and land-atmosphere interactions (see the review paper by Seneviratne et al., 2009). It is important to identify and understand the underlying mechanisms which involve the land-surface and the overlying atmosphere. One of these mechanisms is the feedback process from local evaporation to local precipitation, called "precipitation recycling".

Numerous land-atmosphere interactions and precipitation recycling studies have been performed. Over the central US plains the dominant mechanism is a negative feedback that enhances precipitation recycling during periods of lower precipitation, divergent moisture flux and reduced precipitable water (Zangvil et al., 2001; Ruiz-Barradas and Nigam, 2006; Dominguez and Kumar, 2008). Drier atmospheric conditions lead to higher sensible heat flux and deep boundary layer growth that may promote precipitation (Findell and Eltahir, 2003; Ek and Holtslag, 2004).

In contrast, a positive feedback mechanism is found in a large region extending from northwestern Mexico to the southwestern United States (Small, 2001; Dominguez et al., 2008). Bosilovich et al. (2003) conclude in their

Published by Copernicus Publications on behalf of the European Geosciences Union. 
study with water vapour tracers that the wettest monsoons have mostly continental sources, while drier monsoons have less local sources of precipitation. Positive rainfall anomalies potentially enhance evaporation and subsequent precipitation by decreasing boundary layer height, increasing moist static energy, and increasing instability (Betts et al., 1996; Eltahir, 1998). Schär et al. (1999) conducted several experiments to study the summertime soil moisture-precipitation feedback mechanism over Europe. They suggested that this soil-precipitation feedback relied on some indirect mechanism such as increased moist static stability, which allows wet soils to increase the potential for convective activity.

During extreme dry or wet periods the hydroclimatology of a large region can be abruptly changed. Several studies discussed the moisture sources over the United States during the 1988 drought and 1993 flood (Trenberth and Guillemot, 1996; Dirmeyer and Brubaker, 1999; Bosilovich and Schubert, 2001; Brubaker et al., 2001; Dominguez et al., 2006). These studies found that precipitation recycling was enhanced during the 1988 drought and considerably reduced during the 1993 flood. In these dry and wet periods, land surface memory can provide some predictive potential. Findell and Eltahir (1997) have shown that knowledge of late spring/early summer soil moisture conditions can aid in the prediction of drought or flood years. However, Salvucci et al. (2002) concluded that this evidence was a result of using specific filtering techniques. They found with their Granger causality tests no causal relation between soil moisture and subsequent precipitation in the observations.

Most precipitation recycling studies that have been performed to define the role of land surface-atmosphere interactions focus on monthly or longer time scales. Long time scales however, mask key relationships between precipitation recycling and other variables involving the feedback process that occur at shorter time scales. Zangvil et al. (2004) introduced a model that can be used at a daily time scale. The drawback of this model is that it can only be used for days that have similar large-scale moisture characteristics, but their results show a clear need to analyze the precipitation recycling at shorter time scales.

In this study we apply a newly developed dynamical precipitation recycling model (Dominguez et al., 2006) as a tool for relating precipitation recycling to daily meteorological processes. Bisselink and Dolman (2008) conclude that precipitation recycling only becomes important during years of reduced total precipitation in central Europe. To study in more detail the differences between wet and dry years in moisture recycling, we selected the years, 2003 (dry and warm year with a dry pre-season) and 2006 (dry and warm in July with a wet pre-season) to assess the potential impacts on evaporation and the precipitation recycling ratio. The difference in moisture availability in the pre-season can have impacts in the summer months because of the existence of a land surface moisture memory. In Europe, the risk of

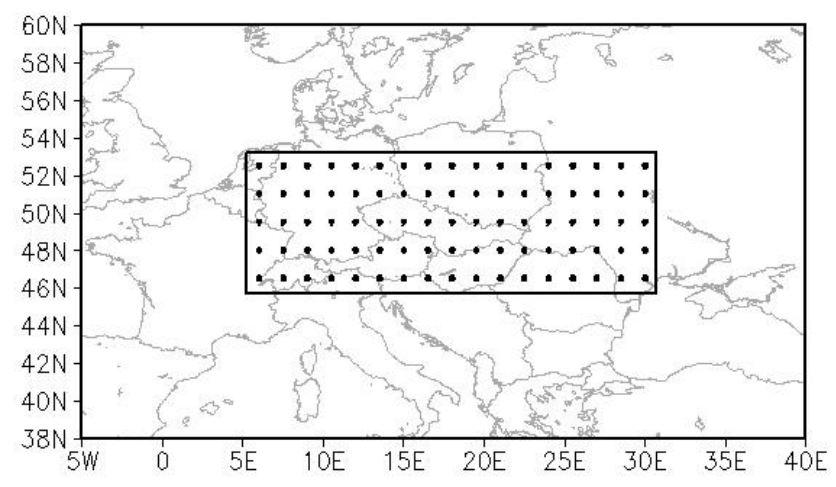

Fig. 1. Area of interest $\left(48.75-53.25^{\circ} \mathrm{N} ; 5.25-11.25^{\circ} \mathrm{E}\right)$. The dots represent the starting point of the backward trajectory calculation.

extreme heat waves like the one of summer 2003 is likely to increase in the future (Beniston, 2004; Meehl and Tebaldi, 2004; Schär et al., 2004; Stott et al., 2004; Vautard et al., 2007). It is therefore important to investigate the contribution of the precipitation recycling in the feedback process in dry periods.

The paper is organized as follows. Section 2 presents the data used in this study. In Sect. 3 we give an overview of the climate in 2003 and 2006. Sect. 4 gives a description of the dynamical precipitation recycling model. The results and interpretations of the land-atmosphere interactions are presented in Sect. 5. Finally, the conclusions and a discussion are presented in Sect. 6 .

\section{Data}

The study area comprises only land over the European continent (Fig. 1). We are interested in the precipitation recycling over land, which is the contribution of evaporation in an area to the precipitation in the same area. Evaporation from the ocean does not depend on the variability of the surface moisture budget, as the surface is always wet (Trenberth, 1999).

In our analysis of the warm season (1 April-30 September) for 2003 and 2006 we use daily variables from the Regional Atmospheric Climate Model (RACMO) at $50 \mathrm{~km} \times 50 \mathrm{~km}$ resolution (Lenderink et al., 2003). The model's domain roughly stretches from $40^{\circ} \mathrm{W}$ to $50^{\circ} \mathrm{E}$ and from $30^{\circ} \mathrm{N}$ to $70^{\circ} \mathrm{N}$. The area of interest (Fig. 1) is located in the center of the domain. ECMWF analyses are used to force the model from the lateral boundaries (Uppala et al., 2005).

The precipitation and evaporation data are completely determined by model physics. Our results could, in principle, be greatly influenced by the assumptions used in the model to calculate variables. In section 6 we will discuss the change in precipitation recycling by the use of a different dataset. However, we believe that consistent data from the RACMO model is the best available for the analysis presented in this 
a)

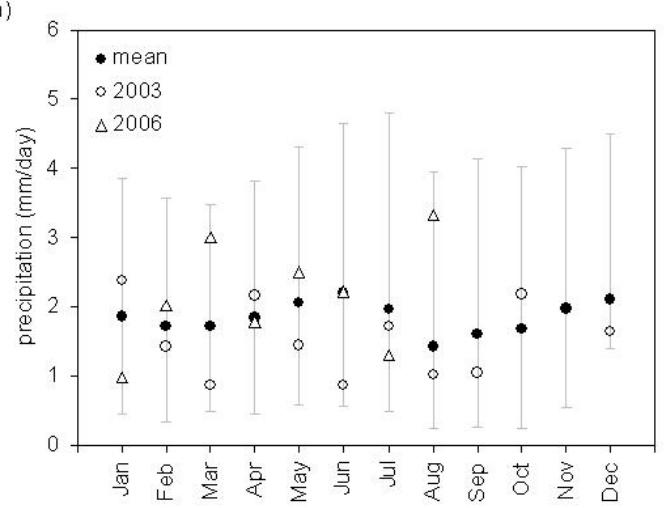

b)

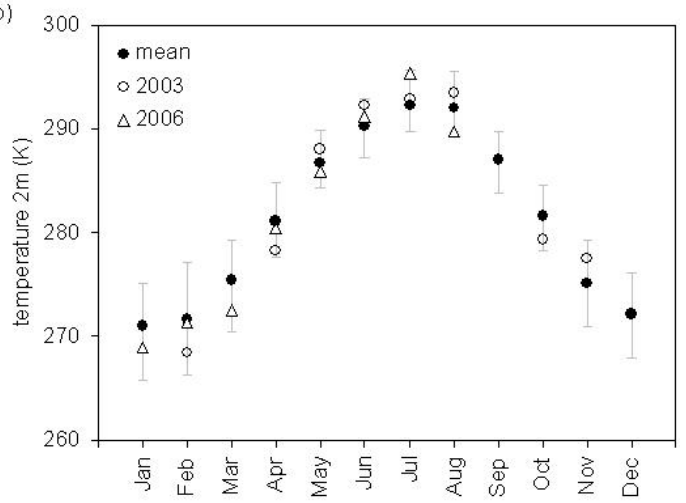

Fig. 2. (a) Precipitation (mm/day) and (b) $2 \mathrm{~m}$ temperature $(\mathrm{K})$ averaged over $48.75-53.25^{\circ} \mathrm{N} ; 5.25-11.25^{\circ}$ E. The filled circles represents the RACMO average monthly values for the period 1981-2000 with corresponding extreme values; the open circles represent the monthly values for 2003 and the triangles represent the monthly values for 2006 (until August due to lack of data).

work. Van den Hurk et al. (2005) showed in a comparison between the modelled and observed average annual cycle of precipitation over the Rhine basin, that the average RACMO precipitation fall within the interannual variability of the observations. More details on the RACMO model can be found in Lenderink et al. (2003).

\section{Climate of 2003 and 2006}

Figure $2 \mathrm{a}$ displays the monthly average precipitation for 2003 and 2006. With the exception of January, April and October, the precipitation in 2003 is lower-than-average. In general, the months preceding the summer are very dry, but still in the range of the extreme values. However, drier than normal conditions start in February and after the very dry May and June, the rainfall deficit increases towards to $69 \mathrm{~mm}$ and persists until the end of the year with the exception of October. In contrast, most months in 2006 have a higher-than-average precipitation. Only January and June are significantly drier than average. Before the start of the dry July, the precipitation surplus exceeds of $32 \mathrm{~mm}$. All precipitation values are within the range of the extreme values.

In 2003, the temperature (Fig. 2b) was exceptionally high from May until the end of August. In June and August, maximum temperature records were broken in many parts of Europe (Black et al., 2004). In July 2003, in contrast to June and August, temperatures were above normal but not record-breaking (Schär et al., 2004; Rebetez et al., 2006). In the dry months, from May until August, the temperatures were much higher-than-average with the exception of the temperatures in July. The extreme temperatures and lack of precipitation in Europe, from May to August 2003, were related to persistent anticyclonic conditions throughout the period (Black et al., 2004). Several studies show the critical role of the spring precipitation deficit to the summer temperatures (Della-Marta et al., 2007; Fischer et al., 2007; Vautard et al., 2007).

In August 2003, the lack of precipitation and the associated depletion of soil moisture results in more sensible heat, inhibiting cloudiness and further increasing daytime temperature (Black et al., 2004). In contrast, in 2006, most of the months are colder than average. In June and July the temperatures are higher-than-average. At the end of June a persistent anticyclonic situation favours the advection of dry and warm air (Rebetez et al., 2008). The temperature of August is lower than the lowest extreme value. Moreover, August is colder than any other month in 1981-2000.

Bisselink and Dolman (2008) concluded that precipitation recycling becomes only important during periods of reduced total precipitation in central Europe at a monthly time scale. For this reason, we selected the years 2003 and 2006 with at least one dry period, but with a different pre-season. We expect the difference in moisture availability in the pre-season to have important consequences for the evaporation and moreover the precipitation recycling in the rest of the season.

\section{Precipitation recycling}

The precipitation recycling ratio is calculated with the dynamical precipitation recycling model of Dominguez et al. (2006). The dynamical precipitation recycling model is derived from the vertically integrated water vapour balance equation:

$$
\frac{\partial w}{\partial t}+\nabla \cdot\left[Q_{\lambda}, Q_{\varphi}\right]=E-P
$$

where the precipitation $(P)$ and the evaporation $(E)$ are averaged directly from the RACMO data and the precipitable water $(w)$ and the vertically integrated moisture fluxes $\left(Q_{\lambda}\right.$ and $Q_{\varphi}$ ) are estimated from the model-data (see Table 1 
Table 1. Derived variables from the RACMO model where $q, u$ and $v$ are the specific humidity and zonal and meridional wind components, respectively.

\begin{tabular}{cll}
\hline Variable & Description & Equation \\
\hline$Q_{\lambda}$ & Vertically integrated average zonal moisture flux & $Q_{\lambda}=\int_{0}^{p_{s}} q u \frac{d p}{g}$ \\
$Q_{\varphi}$ & Vertically integrated average meridional moisture flux & $Q_{\varphi}=\int_{0}^{p_{s}} q v \frac{d p}{g}$ \\
$w$ & Precipitable water & $w=\int_{0}^{p_{s}} q \frac{d p}{g}$ \\
\hline
\end{tabular}

for the precise mathematical definitions). The dynamical precipitation recycling model makes the assumption that the atmosphere is well-mixed. This means that the ratio of advected to evaporated water vapour in the atmospheric column is equal to the ratio of advected precipitation to recycled precipitation $\left(P_{\mathrm{adv}} / P_{r}=w_{\mathrm{adv}} / w_{r}\right)$. Above most land regions the assumption of a well-mixed atmosphere is justified (Eltahir and Bras, 1996). However, according to Bosilovich (2002) the percent contribution of local water is greater in the lower troposphere and less in the middle and upper troposphere. By using an empirical parameter Burde (2006) modified the condition of a well-mixed atmosphere when the mixing of the atmosphere is incomplete. In a subsequent study Burde et al. (2006) applied that method to the Amazon basin, where part of the evaporation may be returned to the regional air/soil interface by "fast recycling". This refers to local showers yielding rain before all cloud water is mixed with the total precipitable water in the average tropospheric column above the region. The regional precipitation recycling ratio values for the Amazon basin, estimated by the modified model, are significantly higher than the values provided by the unmodified model, because of the "fast recycling". Over the central United States the effects of incomplete vertical mixing do not produce significant effects in precipitation recycling. Our results do not incorporate an empirical parameter for "fast recycling". If the atmosphere is not well-mixed and the precipitation will originate from moisture in the lower atmosphere, where recycled moisture dominates, the precipitation recycling ratios may be higher than values provided in a well-mixed atmosphere and therefore the precipitation recycling ratios calculated using the dynamical recycling model may have a bias toward somewhat lower values (Dominguez et al., 2008).

The local precipitation recycling ratio $\rho$ is defined as the ratio of precipitation in a grid cell that originates from evaporation within a region to the total precipitation in that cell $\rho=P_{r} / P$ or $w_{r} / w$ with the well mixed atmosphere assumption. After substituting the definition of the local precipitation recycling ratio, Eq. (1) will transform in a partial differential equation. With a Lagrangian coordinate system $(\chi=x-u t, \xi=y-v t, \tau=t)$, the evaporation as $\varepsilon(\chi, \xi, \tau)$ and the precipitable water as $\omega(\chi, \xi, \tau)$, the expression of the local precipitation recycling ratio $R(\chi, \xi, \tau)$ can now be calculated with of Eq. (2). This coordinate system enables us to follow these paths of the advected moisture flow backwards in time, starting at the dots in Fig. 1, with the moisture-weighted wind velocities $\left(Q_{\lambda} / w\right.$ and $\left.Q_{\varphi} / w\right)$. Time-averaged fields are used as input for the calculation of the precipitation recycling ratios. We calculate the ratio from evaporative origin to total moisture within the column throughout the trajectory at every 6-h time step of the RACMO data, and integrate it from the time the column enters the region until the water precipitates:

$R(\chi, \xi, \tau)=1-\exp \left[-\int_{0}^{\tau} \frac{\varepsilon(\chi, \xi, \tau)}{\omega(\chi, \xi, \tau)} \partial \tau^{\prime}\right]$

The value of $R$ can be transformed back again into the original coordinate system and the value of the local precipitation recycling ratio $\rho$ be determined for every grid cell. Bisselink and Dolman emphasized that $\rho$ is scale dependent. They found that the average summer (June until August) recycling ratio obtained from 23 year ERA-40 reanalysis data (1979-2001) has a logarithmic relationship with the spatial scale for the European continent. To obtain the regional precipitation recycling ratio $r r$, which is the fraction of recycled to total precipitation within a region, we sum the local precipitation recycling ratios in all grid cells weighted by the amount of precipitation falling in each gridcell within the region (Eltahir and Bras, 1994). The advantage of the dynamical precipitation recycling model is that it explicitly incorporates the moisture storage $(\partial w / \partial t)$ term. At a monthly or longer time scale the storage term is negligible compared to the other terms of the water vapour balance equation. The reason that we used the dynamical recycling model is that it allows us to minimize the time step and to calculate recycling at the daily scale. We have now a tool to perform temporal and spatial analysis of the process of precipitation recycling on a daily time scale. A more detailed description of the dynamical precipitation recycling model can be found in Dominguez et al. (2006). 

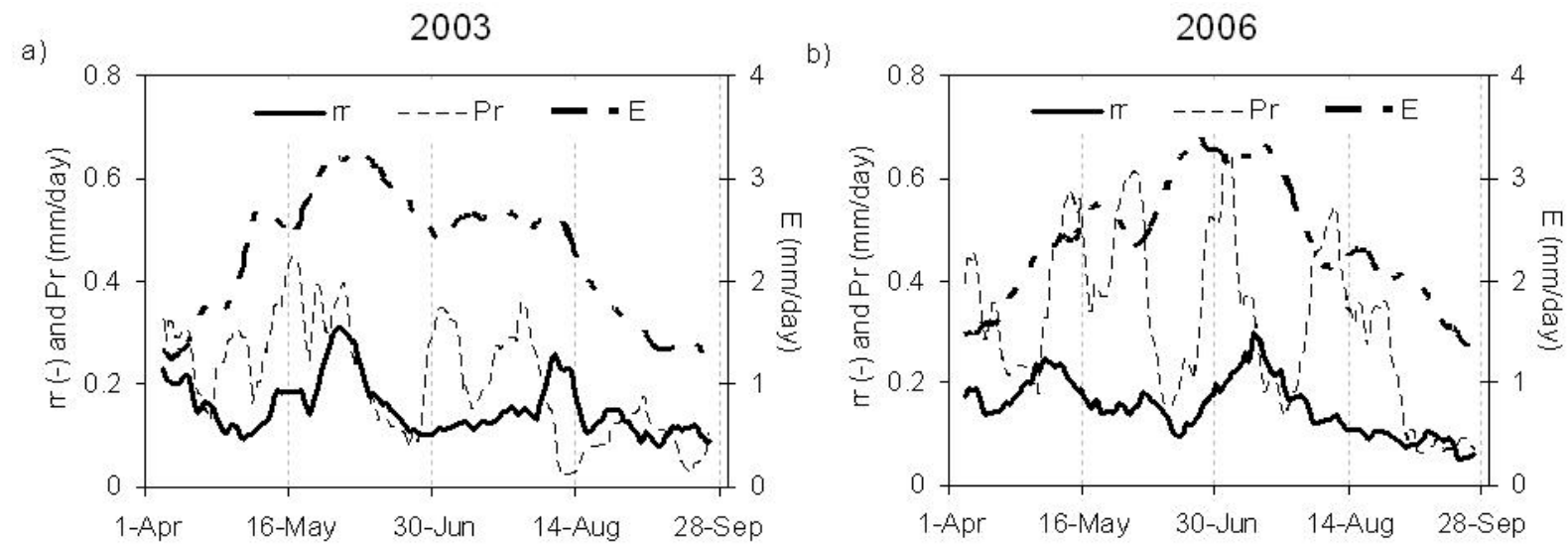

Fig. 3. Time series of the Apr-Sep RACMO 11-day running mean of the daily regional precipitation recycling ratio ( $r r$ ), recycled precipitation $(P r)$ and the evaporation (E) for 2003 (a) and 2006 (b).

\section{Results: precipitation recycling in 2003 and 2006}

\subsection{Daily precipitation recycling ratios}

Figure 3 presents the 11-day running mean of the daily regional precipitation recycling ratio $(r r)$, recycled precipitation (Pr) and the evaporation (E) for 2003 (Fig. 3a) and 2006 (Fig. 3b). The precipitation recycling ratio is generally around 0.15 in 2003 (Fig. 3a) with periods of high precipitation recycling ratios at the end of May/beginning of June and in the first half of August. By multiplying the precipitation recycling ratio with the precipitation we have an estimate of the recycled precipitation $(\mathrm{Pr})$. The recycled precipitation peaks in the second half of May with values of $0.4 \mathrm{~mm} /$ day and in July with values of $0.35 \mathrm{~mm} /$ day. There is a significant negative correlation coefficient of -0.16 between the daily regional precipitation recycling ratio and the daily total precipitation. The correlation is determined by a simple Pearson correlation (significance level 95\%), where the number of degrees of freedom is determined by the number of days between April and the end of September. After the first rains recede in May, the evaporation reaches its highest value after a rapid increase in April and May. At this point the precipitation recycling ratio also peaks. This is the beginning of a warm and very dry month resulting in a lack of soil moisture and a further decrease of the evaporation. In July, after the rain from the beginning of the month, enough moisture is available to keep the evaporation at a stable level but water availability becomes a limiting factor now. After the rains recede in July, the precipitation recycling ratio increases and reaches the second peak in the first half of August. Evaporation is negatively affecting the precipitation recycling in this period due to the lack of water availability caused by the dryness of the preceding spring and summer season. The beginning of August is a very warm and dry period. From mid-August until the end of September, we see a rapid decrease of the evaporation and the precipitation recycling. Throughout the warm season the trend of evaporation is synchronous with the precipitation recycling ratio.

In 2006 (Fig. 3b), the precipitation recycling ratio has an average value of 0.15 with a peak of 0.24 in the beginning of May and a peak of 0.30 at mid-July. The recycled precipitation has several peaks during the season with peaks between 0.4 and $0.6 \mathrm{~mm} /$ day. The daily regional precipitation recycling ratio and the daily total precipitation have a negative correlation coefficient of -0.06 (not significant). After the rains in May, evaporation starts to increase and reaches it's maximum at the end of June. Evaporation remains more or less at the same level because there is enough moisture to evaporate. After the rains recede, the precipitation recycling ratio reaches its maximum. This period is a warm and dry period. At the end of July a different regime starts to dominate the continent with a cold and wet weather pattern. From this moment on, precipitation recycling remains low until the end of September.

In both 2003 and 2006 we observe a peak in the precipitation recycling ratio in the dry periods. This is in good agreement with the findings of Bisselink and Dolman (2008) for their precipitation recycling calculations at a monthly time scale. However, the intraseasonal variability of the precipitation recycling is different between the years. The precipitation recycling and evaporation peak in 2006 is later in the season than in 2003. In 2003 the evaporation and the precipitation recycling peaks are earlier in the season due to the drying out of the soil during summertime. The second peak in precipitation recycling is lower compared to the situation when evaporation was not limited.

To investigate how these variables are related to the precipitation recycling ratio, Fig. 4 shows the 11-day running mean of the precipitable water $(w)$ and the zonal and meridional moisture fluxes, $Q_{\varphi}$ and $Q_{\lambda}$ respectively for 2003 (Fig. 4a) and 2006 (Fig. 4b). In general, the zonal moisture flux is positive and the meridional moisture flux 

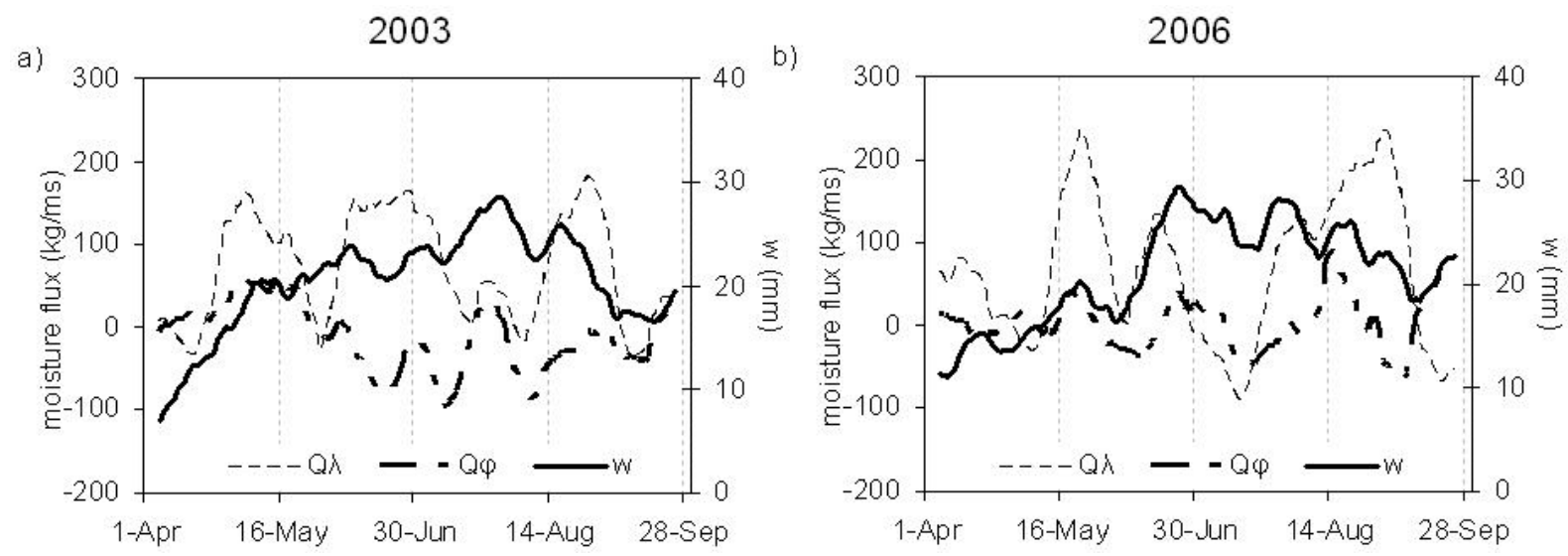

Fig. 4. Time series of the Apr-Sep RACMO 11-day running mean of the regional precipitable water $(w)$, zonal moisture flux $\left(Q_{\lambda}\right)$ and the meridional moisture flux $\left(Q_{\varphi}\right)$ for 2003 (a) and 2006 (b).

is negative in 2003 (Fig. 4a), which implies a moisture transport from the west and north respectively. We observe peaks in the precipitation recycling ratio when the zonal and meridional moisture flux decrease to zero (Fig. 3a). The peaks in the precipitation recycling ratio follow the decrease in the moisture fluxes. The daily regional precipitation recycling ratio and the zonal moisture flux have a negative correlation coefficient of -0.24 (passes $95 \%$ significance). The precipitable water is generally around $20 \mathrm{~mm}$ in 2003 with a peak of $29 \mathrm{~mm}$ at the end of July before the warm period in August. There is a negative correlation coefficient of -0.25 between the daily regional precipitation recycling ratio and the daily precipitable water (passes 95\% significance).

In 2006 (Fig. 4b) the zonal moisture flux shows high peaks, which gives an explanation for the rainfall in May and in August. Again the precipitation recycling ratio (Fig. 3b) follows the decrease in moisture flux. The daily regional precipitation recycling ratio and the zonal moisture flux have a negative correlation coefficient of -0.49 (passes $95 \%$ significance). The precipitable water is generally around $21 \mathrm{~mm}$ with a peak of $29 \mathrm{~mm}$ at the end of June when we see a peak in precipitation of recycled origin and a maximum in evaporation. There is a negative correlation coefficient of -0.31 between the daily regional precipitation recycling ratio and the daily precipitable water (passes $95 \%$ significance). In both 2003 and 2006, precipitation recycling becomes important when the moisture from advective origin is small. When the moisture fluxes are small, the air will have a longer residence time in the study area to capture moisture from evaporative origin.

The precipitation recycling is calculated with the dynamical precipitation recycling model and is dependent on evaporation, precipitable water, moisture fluxes and precipitation. We applied a Granger Causality test (Granger, 1969; Granger, 1980) to identify whether evaporation, precipitable water, moisture fluxes and precipitation are useful in forecasting the precipitation recycling ratio. We focused on one-day ahead conditioning of the precipitation recycling ratio. The Granger Causality null hypothesis assumes no significant impact of changed evaporation, precipitable water, moisture fluxes or/and precipitation on the precipitation recycling ratio. We reject the null hypothesis at the 90\% confidence level. For 2003, the Granger Causality supports the conclusion that the precipitation recycling ratio is governed by evaporation $(p<0.002)$, precipitable water $(p<0.005)$ and the zonal moisture flux $(p<0.12)$. For 2006 , the zonal moisture flux $(p<0.007)$, the precipitable water $(p<0.03)$ and the evaporation $(p<0.10)$ provide a causal factor in explaining the precipitation recycling ratio.

In 2003, evaporation exerts the most significant Granger causal impact on the precipitation recycling ratio. In 2006, a wet year, the precipitable water is the most important factor. Thus, we find that in dry years the evaporation becomes more important. Savenije (1996) concluded that recycling of moisture is the most important source of rainfall in semiarid or arid areas. Years of high precipitation will generally have higher evaporation and precipitation and precipitation recycling are generally negatively correlated. It is expected that the Granger Causality test for evaporation will not be significant in extreme wet years (wetter than 2006).

\subsection{Spatial variability}

In order to gain understanding of the spatial distribution of the variables that modulate the precipitation recycling, we focus again our attention on the year 2003 and 2006. Figures 5 and 6 show the average of the daily local precipitation recycling ratio $(\rho)$, evaporation $(E)$ and precipitation $(P)$ for the years 2003 and 2006, respectively. In general, we expect that the eastern part of the study 

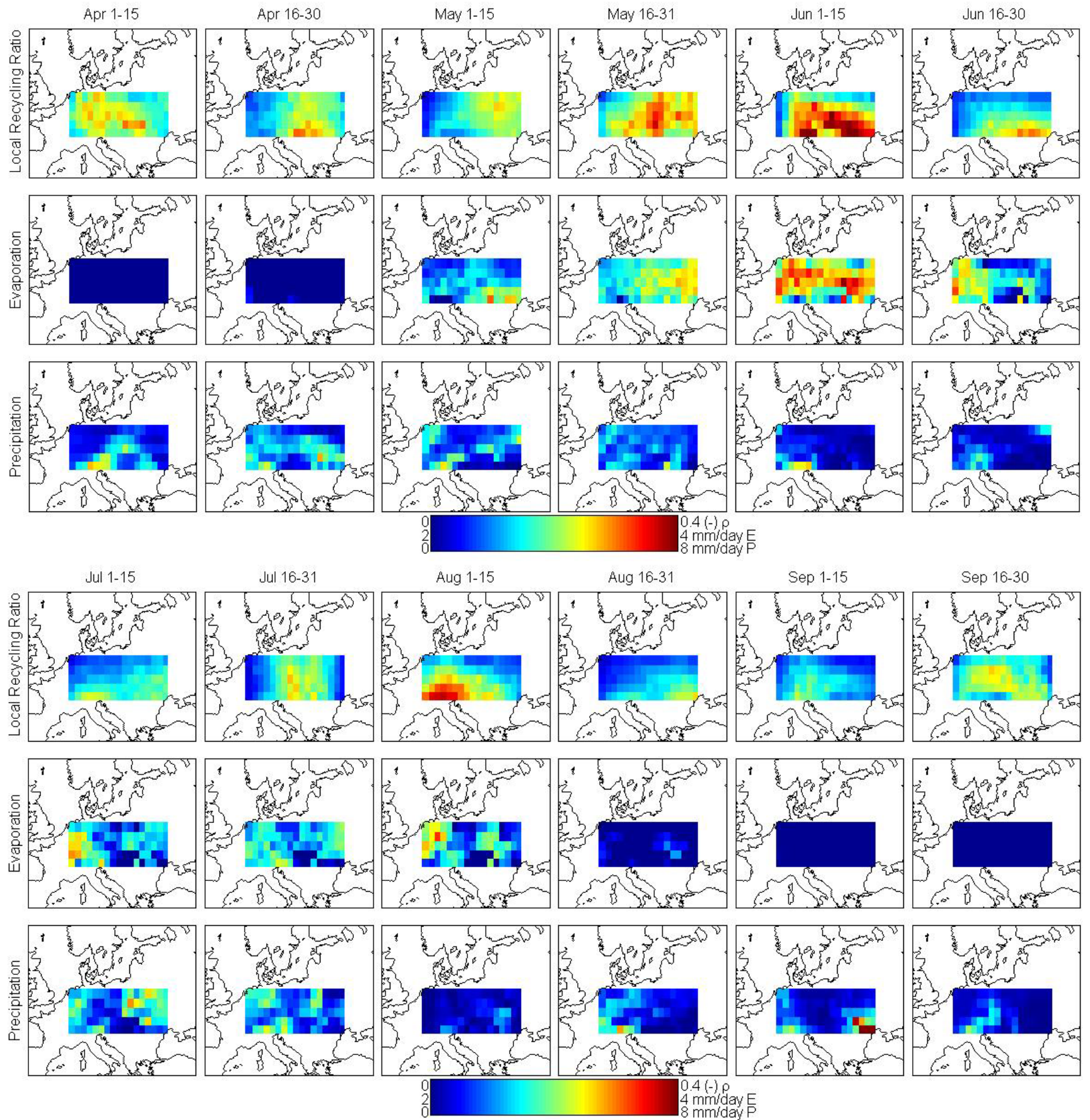

Fig. 5. Average daily local precipitation recycling ratio $\rho(-)$, evaporation $E(\mathrm{~mm} /$ day $)$ and precipitation $P(\mathrm{~mm} /$ day $)$ for 2003 . The 15 -day panels go from the beginning of April to the end of September.

area has the highest precipitation recycling ratio. In central Europe the westerly circulation is dominant and the eastern part of the study area corresponds to the longest paths of moisture.

At the end of May and in the beginning of June (Fig. 5) a high pressure cell starts to dominate the synoptic situation of the study area. The moisture flux is almost stagnant with little advection. The air in the study area will have a longer residence time and have more time to capture moisture of evaporative origin. Consequently, we see a peak in the precipitation recycling ratio. The evaporation is high in the entire region, while the precipitation is very low. From this point on, evaporation decreases throughout the rest of the season with the exception of the beginning of August. A 

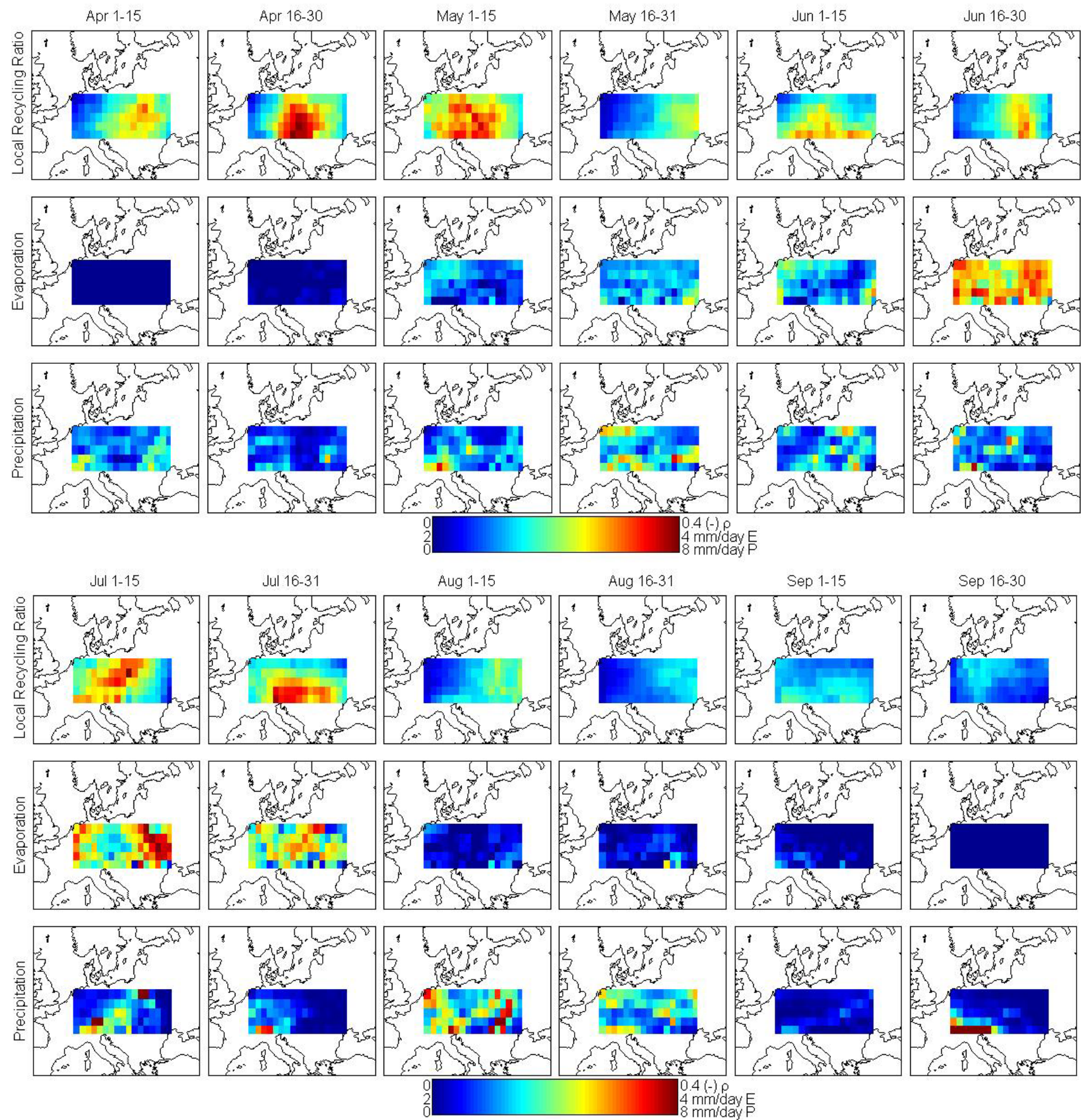

Fig. 6. Same as in Fig. 5 but for 2006.

second peak in the precipitation recycling ratio in the first part of August is preceded by rainfall in July in the west part of the study area. During periods of high precipitation recycling and evaporation, the total precipitation is very low due to the presence of a high pressure cell. Consequently, the recycled precipitation will be low in periods of reduced total precipitation. However, evaporation remains a major contributor to precipitation in periods of high precipitation recycling.
The season of 2006 starts with high precipitation recycling ratio at the end of April and beginning of May. At the end of April it is clearly noticeable that the precipitation recycling ratio and precipitation are negatively correlated. In this period a Siberian anticyclone is widespread over almost the entire continent. The pressure gradient over the continent is very low with low moisture advection and high precipitation recycling ratios. The high evaporation rates in the second half of June are followed by high precipitation recycling 

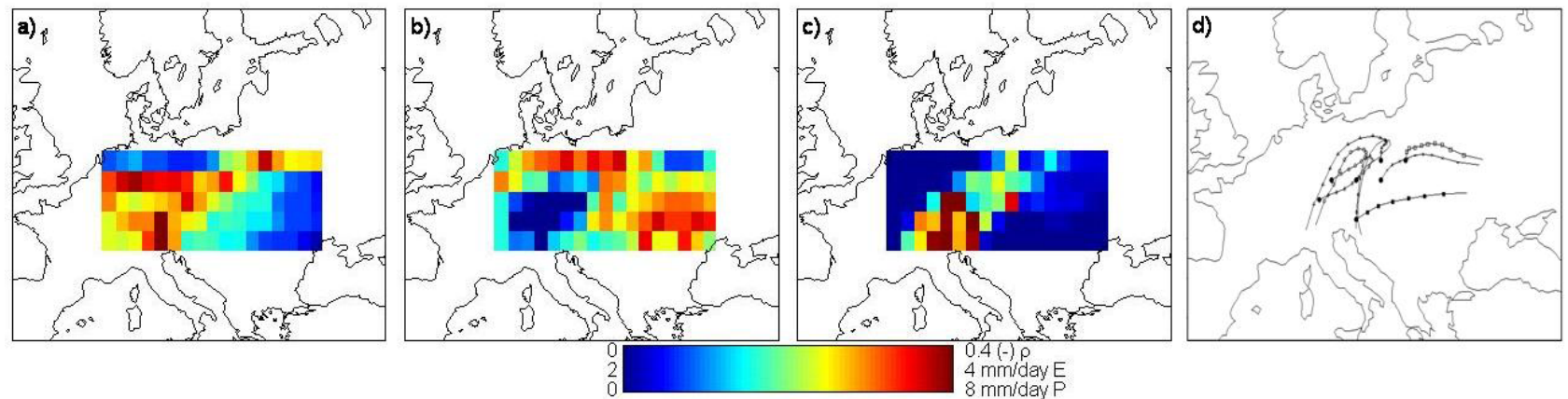

Fig. 7. 28 May 2003 (a) local precipitation recycling ratio $\rho$ (b) evaporation $E$ (c) precipitation $P$ and (d) selected paths to show the origin of moisture for the regions of high precipitation recycling and precipitation. Each selected path corresponds to a grid point (black dots) and has been traced back until the time the moist air entered the region.
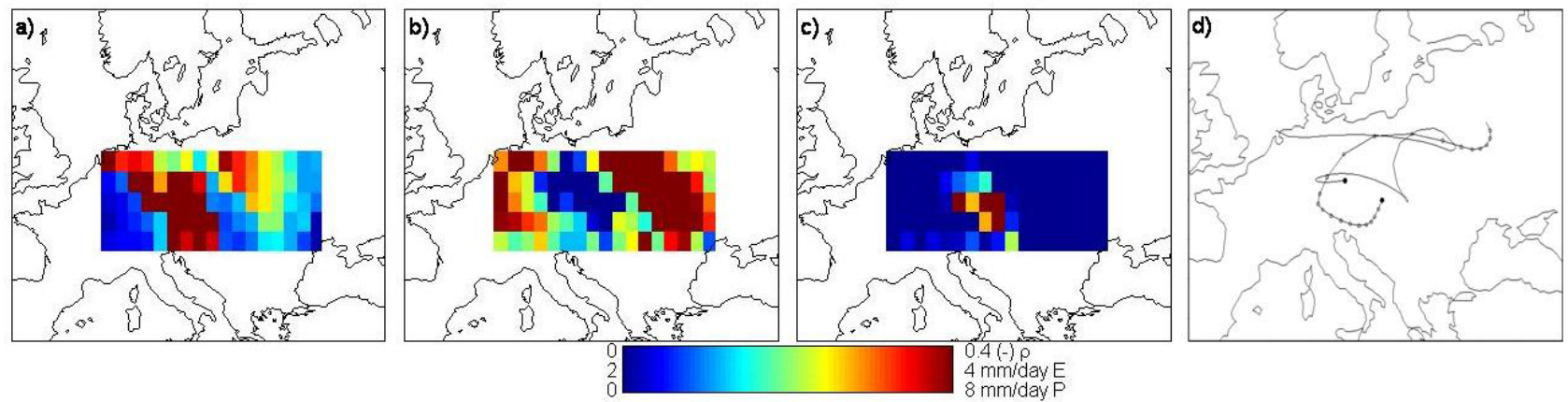

Fig. 8. 5 July 2006 (a) local precipitation recycling ratio $\rho$ (b) evaporation $E$ (c) precipitation $P$ and (d) two selected paths to show the origin of moisture for the regions of high precipitation recycling and precipitation. Each selected path corresponds to a grid point (black dots) and has been traced back until the time the moist air entered the region.

ratios in July. From the end of July, a different regime starts to dominate with considerable moisture advection from the ocean which remains until the end of the season and suppress the precipitation recycling ratio.

\subsection{Case studies}

So far we discussed the dynamics of the precipitation recycling using spatially averaged data and the spatial distribution of the variables. In the next figures (Figs. 7, 8, 9 ), we present the analysis for 3 selected days that show one of the highest regional precipitation recycling ratios. We will discuss the role of moisture recycling as an important process in land-atmosphere interactions.

In the situation of 28 May 2003, the areas of highest precipitation recycling are confined to the west of a line from southwest to northeast (Fig. 7a). The areas of intense evaporation however, are in the areas where the precipitation recycling is low (Fig. 7b). Precipitation falls in a line from southwest to northeast where colder and warmer air converge (Fig. 7c). Selected paths for the region of highest precipitation recycling ratios are plotted in Fig. 7d. The paths are defined by the $u$ and $v$ velocities (the zonal and meridional moisture flux divided by the total precipitable water). Throughout the trajectory we calculate the ratio of moisture from evaporative origin to total moisture within the column, and integrate it from the time the column enters the region until the water precipitates. The spatial variability of evaporation translates into different $\varepsilon / \omega$ ratios throughout the paths. In general, evaporation becomes important in the precipitation recycling process when moisture of advective origin diminishes. The air has more time to traverse the region and capture moisture of evaporative origin. Following the paths in the precipitation zone, we notice that the trajectory enters the region from the east and from the south, respectively. The air mass, originating from the east, has a dry origin but picks up moisture throughout its trajectory before it precipitates. The origin of the air mass from the south, belonging to a low pressure system east of Spain, already contains moisture. However, the air is first transported north and later to the south and is able to pick up moisture before its precipitates. In this precipitation event, evaporation significantly contributes to the moisture content. However, it is questionable if the precipitation event had occurred when the original moisture source was not from oceanic origin. 

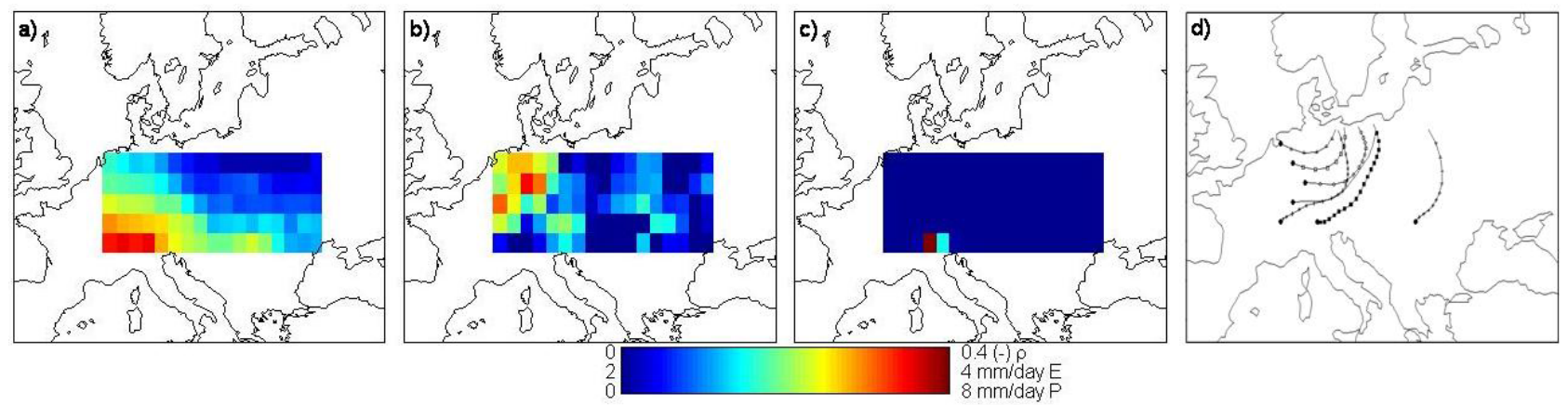

Fig. 9. 10 August 2003 (a) local precipitation recycling ratio $\rho$ (b) evaporation $E$ (c) precipitation $P$ and (d) selected paths to show the origin of moisture for the regions of high precipitation recycling. Each selected path corresponds to a grid point (black dots) and has been traced back until the time the moist air entered the region.

At 5 July 2006, the areas with the highest precipitation recycling ratio are located in central Europe where an anticyclone with less pressure gradient dominates the synoptic situation (Fig. 8a). In the southwest part of the region the winds are already increasing which decrease the precipitation recycling ratio. The evaporation is intense in the east part of the study area (Fig. 8b) and precipitation is falling in the area of high precipitation recycling (Fig. 8c). In Fig. 8d two paths of the region of highest precipitation are plotted. Following the trajectory, we see that winds enter the region from the west, origin from the ocean, and east, respectively. However, in both paths the air is transported for a very long distance over land before it precipitates. The air has considerable time to traverse the region and capture moisture of evaporative origin which now significantly contributes to the precipitation.

In the situations of 28 May 2003 and 5 July 2006 enough moisture storage is available and a mechanism to trigger precipitation exists. The precipitation falling at those days originates (partly) from oceanic sources, but the triggering of precipitation may itself be a result of enhanced instability induced by soils, which still have enough moisture storage. In this way, the evaporation is an important driver in the precipitation recycling ratio variability and the generation of rainfall in dry periods. Both days are in warm periods where the sensible heat flux is getting more dominant. Under these conditions a deep cloud-base height is needed for clouds to form and convective precipitation to occur. This land-atmosphere interaction is an example of a negative feedback (Findell and Eltahir, 2003; Ek and Holtslag, 2004). Ek and Holtslag (2004) showed that this is only valid in situations with weak atmospheric instability above the boundary layer.

In August 2003, evaporation is limited because of the preceded warm period. The synoptic situation of $10 \mathrm{Au}$ gust 2003 (Fig. 9) is dominated by an anticyclone above Scandinavia associated with a clockwise air movement. Logically, the highest precipitation recycling ratios are southwest of the study area (Fig. 9a) while the areas of intense evaporation are located more north (Fig. 9b). In the rest of the region the evaporation is very low. The precipitation rate is very low, except for the mountainous region due to orographic lifting (Fig. 9c). The strong high pressure system is typically accompanied by subsidence, clear skies and warm-air advection from the east, which prolonged hot conditions at the surface. We hypothesize that the air is too dry to generate precipitation with exception of mountainous areas. The air at 10 August (Fig. 9d) enters the region from the north and is then transported to the west, because of the anticyclonic wind. Evaporation in the region is low and does not significantly contribute to the moisture content with exception of mountainous regions.

\section{Concluding remarks}

We applied a dynamical precipitation recycling model which incorporates time dependent moisture storage. The model can, therefore, be used to study precipitation recycling ratios at a daily time scale. One of the limitations of the model is the assumption of a well-mixed atmosphere. Moreover, the model remains scale dependent and, therefore, results must be interpreted with some caution.

Our study uses daily variables from RACMO with the domain roughly stretches from $40^{\circ} \mathrm{W}$ to $50^{\circ} \mathrm{E}$ and from $30^{\circ} \mathrm{N}$ to $70^{\circ} \mathrm{N}$. The analysis is focused on the warm season (1 April-30 September) for the years 2003 and 2006. Bisselink and Dolman (2008) conclude that precipitation recycling only becomes important during periods of reduced total precipitation in central Europe at a monthly time scale. However, they were unable to look into the differences between very wet and dry years in detail. In this study we selected the years 2003 and 2006 for further analysis. The warm season of 2003 is characterized with a dry pre-season and two heat wave periods, June and August. The summer of 2006 also has a heat wave period, but the season started with higher-than-average precipitation. We are interested in 
the potential impacts on the evaporation and precipitation recycling ratio in both 2003 and 2006. The difference in moisture availability in the pre-season can have impacts in the summer months because of the potential of the land surface moisture memory to impact precipitation.

The results presented in this study are dependent upon the quality of the model-data used. The precipitation and evaporation data are completely determined by model physics, and therefore rely on the assumption made in the model. Precipitation and evaporation are the most critical variables. In order to evaluate the precipitation recycling ratios obtained with RACMO, we tested our results by estimating the precipitation recycling ratios and the variables using the ECMWF operational data set. The precipitation recycling ratios using the ECMWF dataset are very similar to those obtained with the RACMO model for 2003. For 2006, the precipitation recycling ratios using ECMWF data are slightly higher than the RACMO estimates due to higher precipitation and evaporation rates. We believe that the results presented here are not affected by this difference, because the precipitation recycling is enhanced in dry periods.

Our analysis reveals that, over central Europe, the precipitation recycling ratios are negatively correlated to precipitation, precipitable water and the moisture fluxes for both 2003 and 2006. However, the negative correlation to precipitation in 2006 is not significant. Bisselink and Dolman (2008) concluded in their study at a monthly scale that evaporation contributes to precipitation only in dry years. Here, at a daily time scale, we hypothesize that in dry spells (also in wet years) the precipitation recycling plays a significant role in triggering of precipitation, even if the total amount of precipitation is small.

In wet periods, when the moisture fluxes are large, the contribution of evaporation is limited most of the time. When the moisture fluxes diminish local evaporation becomes an important contributor to precipitation. In a weak circulation the air has more time to traverse the region and capture moisture from evaporative origin to contribute to precipitation. As precipitation decreases, evaporation will continue if there is enough moisture storage in the soil. In this situation we propose a negative feedback as discussed in Findell and Eltahir (2003) and Ek and Holtslag (2004) where evaporation continues to feed moisture into the overlying atmosphere and contribute to rainfall. Drier atmospheric conditions lead to higher sensible heat. A deep boundary layer growth is then needed to form clouds and to trigger convective precipitation. On 28 May 2003 and 5 July 2006, the circulation is weak and a long terrestrial fetch allows for a larger proportion of land evaporation to contribute to precipitation. However, we hypothesize that the precipitation falling at those days originates (partly) from oceanic sources, but the triggering of precipitation may itself be a result of enhanced instability induced by soils, which still have enough moisture storage.
When the land is too dry and evaporation is a limiting factor, the contribution of evaporation to precipitation is low despite the weak circulation. According to a Granger Causality test, the evaporation exerts the most Granger causal impact on the precipitation recycling ratio in a dry year. At 10 August 2003, the air is to dry to generate precipitation. The evaporation is affecting the precipitation recycling due to the lack of water availability caused by the dryness of the preceding spring and summer season.

In dry periods with enough moisture available precipitation recycling acts as a mechanism to keep the precipitation at a stable level. In extreme dry periods the contribution of evaporation to precipitation is marginal. In Europe, the risk of extreme heat waves, like the one of summer 2003, is likely to increase in the future (Beniston, 2004; Meehl and Tebaldi, 2004; Schär et al., 2004; Stott et al., 2004; Vautard et al., 2007). For this reason, the present work can help to improve the understanding on the impact of land-use change on evaporation in these dry spells that are dominated by persistent blocking systems.

Acknowledgements. This work was carried out within the framework of the ACER project under the Dutch National Research Program "Climate Changes Spatial Planning." The RACMO data was generously provided by E. van Meijgaard and B. van den Hurk.

Edited by: B. Schaefli

\section{References}

Beniston, M.: The 2003 heat wave in Europe. A shape of things to come?, Geophys. Res. Lett., 31, L02202, doi:10.1029/2003GL018857, 2004.

Betts, A. K., Ball, J. H., Beljaars, A. C. M., Miller, M. J., and Viterbo, P. A.: The land surface-atmosphere interaction: A review based on observational and global modeling perspectives, J. Geophys. Res., 101, 7209-7225, 1996.

Bisselink, B. and Dolman, A. H.: Precipitation recycling: Moisture sources over Europe using ERA-40 data, J. Hydrometeorol., 9, 1073-1083, 2008.

Black, E., Blackburn, M., Harrison, G., Hoskins, B., and Methven, J.: Factors contributing to the summer 2003 European heatwave, Weather, 59, 217-223, 2004.

Bosilovich, M. G.: On the vertical distribution of local and remote sources of water for precipitation, Meteorol. Atmos. Phys., 80, 31-41, 2002.

Bosilovich, M. G. and Schubert, S. D.: Precipitation recycling over the central United States diagnosed from the GEOS-1 data assimilation system, J. Hydrometeorol., 2, 26-35, 2001.

Bosilovich, M. G., Sud, Y. C., Schubert, S. D., and Walker, G. K.: Numerical simulation of the large-scale North American monsoon water sources, J. Geophys. Res., 108(D16), 8614, doi:10.10292002JD003095, 2003.

Brubaker, K. L., Dirmeyer, P. A., Sudradjat, A., Levy, B. S., and Bernal, F.: A 36-yr climatological description of the evaporative 
sources of warm-season precipitation in the Mississippi River basin, J. Hydrometeorol., 2, 537-557, 2001.

Brubaker, K. L., Entekahabi, D., and Eagleson, P. S.: Estimation of precipitation recycling, J. Climate, 6, 1077-1089, 1993.

Burde, G. I.: Bulk recycling models with incomplete vertical mixing. Part I: Review of recycling models, J. Climate, 19, 1461-1472, 2006.

Burde, G. I., Gandush, C., and Bayarjargal, Y.: Bulk recycling models with incomplete vertical mixing: Part II: Precipitation recycling in the Amazon Basin, J. Climate, 19, 1473-1489, 2006.

Della-Marta, P. M., Haylock, M. R., Luterbacher, J., and Wanner, H.: Doubled length of western European summer heat waves since 1880, J. Geophys. Res., 112, D15103, doi:10.1029/2007JD008510, 2007.

Della-Marta, P. M., Luterbacher, J., vonWeissenfluh, H., Xoplaki, E., Brunet, M., and Wanner, H.: Summer heat waves over western Europe 1880-2003, their relationship to large-scale forcings and predictability, Clim. Dynam., 29, 251-275, 2007.

Dirmeyer, P. A. and Brubaker, K. L.: Contrasting evaporative moisture sources during the drought of 1988 and the flood of 1993, J. Geophys. Res., 104(D16), 19383-19397, 1999.

Dominguez, F. and Kumar, P.: Precipitation recycling variability and ecoclimatological stability - A study using NARR data. Part I: Central U.S. plains ecoregion, J. Climate, 5165-5186, 2008.

Dominguez, F., Kumar, P., Liang, X., and Ting, M.: Impact of atmospheric moisture storage on precipitation recycling, J. Climate, 19, 1513-1530, 2006.

Dominguez, F., Kumar, P., and Vivoni, E. R.: Precipitation recycling variability and ecoclimatological stability - A study using NARR data. Part II: North American Monsoon Region, J. Climate, 5187-5203, 2008.

Ek, M. and Holtslag, A. M. M.: Influence of soil moisture on boundary layer cloud development, J. Hydrometeorol., 5, 86-99, 2004.

Eltahir, E. A. B.: A Soil Moisture-Rainfall Feedback Mechanism, 1. Theory and Observations, Water Resour. Res., 34, 765-776, 1998.

Eltahir, E. A. B. and Bras, R. L.: Precipitation recycling in the Amazon basin, Q. J. Roy. Meteor. Soc., 120, 861-880, 1994.

Eltahir, E. A. B. and Bras, R. L.: Precipitation recycling, Rev. Geophys., 34, 367-378, 1996.

Findell, K. L. and Eltahir, E. A. B.: An analysis of the soil moisture-rainfall feedback, based on direct observations from Illinois, Water Resour. Res., 33, 725-735, 1997.

Findell, K. L. and Eltahir, E. A. B.: Atmospheric controls on soil moisture-boundary layer interactions. Part I: Framework development, J. Hydrometeorol., 4, 552-569, 2003.

Fischer, E. M., Seneviratne, S. I., Lüthi, D., and Schär, C.: Contribution of land-atmosphere coupling to recent European summer heat waves, Geophys. Res. Lett., 34, L06707, doi:10.1029/2006GL029068, 2007.

Granger, C. W. J.: Investigating causal relationships by econometric models and cross spectral models, Econometrica, 37, 424-438, 1969.

Granger, C. W. J.: Testing for causality, A personal viewpoint, J. Econ. Dyn. Control, 2, 329-352, 1980.

Lenderink, G., van den Hurk, B., van Meijgaard, E., van Ulden, A. P., and Cuijpers, J. H.: Simulation of present-day climate in RACMO2: first results and model developments, KNMI
Technical Report 252, 24 pp., 2003.

Meehl, G. A. and Tebaldi, C.: More intense, more frequent, and longer lasting heat waves in the 21 st century, Science, 305, 994997, 2004.

Rebetez, M., Dupont, O., and Giroud, M.: An analysis of the July 2006 heatwave extent in Europe compared to the record year of 2003, Theor. Appl. Climatol., 95, 1-7, 2009.

Rebetez, M., Mayer, H., Dupont, O., Schindler, D., Gartner, K., Kropp, J., and Menzel, A.: Heat and drought 2003 in Europe: a climate synthesis, Ann. For. Sci., 63, 569-577, 2006.

Ruiz-Barradas, A. and Nigam, S.: Great Plains hydroclimate variability: The view from North American Regional Re-analysis, J. Climate, 19, 3004-3010, 2006.

Salvucci, G. D., Saleem, J. A., and Kaufmann, R.: Investigating soil moisture feedbacks on precipitation with tests of Granger causality, Adv. Water Resour., 25, 1305-1312, 2002.

Seneviratne, S. I., Corti, T., Davin, E. L., Hirschi, M., Lehner, I., and Teuling, A. J.: Investigating soil moisture-climate interactions in a changing climate: A review, Earth-Sci. Rev., submitted, 2009.

Savenije, H. H. G.: The runoff coefficient as the key to moisture recycling, J. Hydrology, 176, 219-225, 1996.

Schär C., Lüthi D., Beyerle U., and Heise, E.: The Soil-Precipitation Feedback: A Process Study with a Regional Climate Model, J. Climate, 12, 722-741, 1999.

Schär, C., Vidale, P. L., Lüthi, D., Frei, C., Häberli, C., Liniger, M., and Appenzeller C.: The role of increasing temperature variability in European summer heat waves, Nature, 427, 332-336, 2004.

Small, E. E.: The influence of soil moisture anomalies on variability of the North American monsoon system, Geophys. Res. Lett., 28, 139-142, 2001.

Stott, P. A., Stone, D. A., and Allen, M. R.: Human contribution to the European heatwave of 2003, Nature, 432, 610-614, 2004.

Trenberth, K. E.: Atmospheric moisture recycling: Role of advection and local evaporation, J. Climate, 12, 1368-1381, 1999.

Trenberth, K. E. and Guillemot, C. J.: Physical processes involved in the 1988 drought and 1993 floods in North America, J. Climate, 9, 1288-1298, 1996.

Uppala, S. M., Kållberg, P. W., Simmons, A. J., Andrae, U., da Costa Bechtold, V., Fiorino, M., Gibson, J. K., Haseler, J., Hernandez, A., Kelly, G. A., Li, X., Onogi, K., Saarinen, S., Sokka, N., Allan, R. P., Andersson, E., Arpe, K., Balmaseda, M. A., Beljaars, A. C. M., van de Berg, L., Bidlot, J., Bormann, N., Caires, S., Chevallier, F., Dethof, A., Dragosavac, M., Fisher, M., Fuentes, M., Hagemann, S., Hólm, E., Hoskins, B. J., Isaksen, L., Janssen, P. A. E. M., Jenne, R., McNally, A. P., Mahfouf, J. -F., Morcrette, J. -J., Rayner, N. A., Saunders, R. W., Simon, P., Sterl, A., Trenberth, K. E., Untch, A., Vasiljevic, D., Viterbo, P., and Woollen, J.: The ERA-40 re-analysis, Q. J. Roy. Meteor. Soc., 131, 2961-3012, 2005.

Van den Hurk, B., Hirschi, M., Schär, C., Lenderink, G., van Meijgaard, E., van Ulden, A., Rockel, B., Hagemann, S., Graham, P., Kjellström, E., and Jones R.: Soil control on runoff response to climate change in regional climate model simulations, J. Climate, 17, 3536-3551, 2005.

Vautard, R., Yiou, P., D'Andrea, F., de Noblet, N., Viovy, N., and Cassou, C.: Summertime European heat and drought waves 
induced by wintertime Mediterranean rainfall deficit, Geophys. Res. Lett., 34, L07711, doi:10.1029/2006GL028001, 2007.

Zangvil, A., Portis, D. H., and Lamb, P. J.: Investigation of the large-scale atmospheric moisture field over the midwestern United States in relation to summer precipitation. Part I: Relationship between moisture budget components on different time scales, J. Climate, 14, 582-597, 2001.
Zangvil, A., Portis, D. H., and Lamb, P. J.: Investigation of the large-scale atmospheric moisture field over the Midwestern United States in relation to summer precipitation. Part II: Recycling of local evapotranspiration and association with soil moisture and crop yields, J. Climate, 17, 3283-3301, 2004. 